\title{
Does Economic Growth Reduce Pollution? Empirical Evidence from Low Income Countries
}

\author{
Mohammad Rofiuddin ${ }^{1, *}$, Siti Aisyah ${ }^{2}$, Desy Nur Pratiwi ${ }^{3}$, Arna Asna Annisa ${ }^{1}$, Rosana Eri Puspita ${ }^{1}$, and Rifda Nabila $^{1}$ \\ ${ }^{1}$ Faculty of Islamic Economics and Business, IAIN Salatiga - Indonesia \\ ${ }^{2}$ Faculty of Economics and Business, Muhammadiyah University, Surakarta - Indonesia \\ ${ }^{3}$ Sekolah Tinggi Ilmu Ekonomi AAS - Indonesia
}

\begin{abstract}
The issue of environmental degradation has long been associated as a residue of the economic development process, especially in low income countries. Development activities have to continue nevertheless, because people's welfare is the goal. This study aims to find the impact of economic growth, population and energy consumption to environmental pollution. Another purpose is to prove the Environmental Kuznets Curve (EKC) hypothesis. The methods utilized is panel data regression with fixed effect model using Drisscol-Kraay estimator. The result of the study indicates that increased per capita GDP and population leads to environmental pollution in low income countries, while energy consumption has no significant effect. The result also confirmed the EKC hypothesis in low income countries.
\end{abstract}

Keywords: Environment Kuznets curve; Economic growth; Population Density; Energy Consumption; Low income countries

\section{Introduction}

The development of a country's economy has a sole purpose that is to improve the welfare of the people, numerous effort has been carried out by governments in many countries to meet their development goals. But environmental issues in the form of pollution and general environmental degradation are often the indirect result of achieving these goals $[1,2]$. This particular condition pose a serious problem to developing countries where on the one hand the rapid economic growth is favorable [3], the environmental damage on the other hand is inevitable.

The process of various economic activities and the benefit of economic growth often time takes a toll in maintaining the quality of the environment. The effect of unsustainable growth manifested in decreasing natural resources, in both number and quality, pollutions on the land, water body and air, the shifting function of green open space to cater the industrial and residential needs for land. This has made economic development particularly in least developed and developing countries difficult to be harmoniously implemented with attempts to conserve the nature [4]. The irony of increased economic growth and deteriorate environment has led many researchers conducted to find the relationship and to examine the theory between these issues.

The industrial revolution has brought along the idea of increased national welfare through maximized economic growth by heavily exploiting resources, especially non sustainable natural resources [5]. This condition is also a result of competition among countries to be the next economic power house, increased level of greenhouse gas emission particularly $\mathrm{CO}_{2}$ emission was the immediate impact to the environment. Overtime the environmental damage caused a global concern that is global warming and the thinning of ozone layer. During the industrial revolution, the global average of surface temperature of the $20^{\text {th }}$ century has risen $0.6^{\circ} \mathrm{C}$, snow and ice coverage declined by $10 \%$, sea level increased by 10 to $20 \mathrm{~cm}$, all of these are projected to increase during the 21 th century[6].

Experts have been explaining the relationship between economic growth and environmental pollution using Environmental Kuznets Curve (EKC). EKC hypothesis explains that initial income growth will result in increased level of environmental damage to a certain point where income growth leads to lower level of environmental damage $[7,8]$. The assumption is higher economic growth will bring about better facilities. Based on EKC concept, $\mathrm{CO}_{2}$ emission is expected to have a positive correlation to income growth before the turning point of EKC, and a negative correlation after the turning point.

Initial research on the subject of the relationship between economic growth and environmental Kuznets curve are numerous [2, 8-11], explained in their respective research that per capita Gross Domestic Product (GDP) has a positive relationship to $\mathrm{CO}_{2}$ emission and prove that there is an inverted $\mathrm{U}$ shape. While [1, 4, 12-14], did not find the inverted Kuznets curve in their research. Other researcher, [7, 15-18],

\footnotetext{
* Corresponding author: mohammad.rofiuddin@iainsalatiga.ac.id
} 
came to conclusion that there are correlation between economic growth and $\mathrm{CO}_{2}$ emission, but [19] did not find any correlation between economic growth and $\mathrm{CO}_{2}$ emission in their research. This empirical research found a different phenomenon in relation to research findings on economic growth and $\mathrm{CO}_{2}$ emission.

Aside from the commonly agreed economic growth impact on pollution, there are other sources of pollution namely population growth and energy consumption. The correlation between population and environment has been describe by Malthus in 1798, which prove that the growth of population will eventually reach the limit of resource base in the absence of technological progress [16].

The result of empirical studies explained the that population has a significant impact on emission [1]. Bella conveyed in her research that population gives a significant burden to nature [20].

Other studies on the relationship between energy consumption and environment proved that energy consumption is the most significant variable in explaining carbon emission [21]. other studies share similar findings on the impact of energy consumption to greenhouse gas emission [1,8]. Evidence on correlation between energy consumption and air pollution is thoroughly explained [22]. While other empirical study found that energy consumption has a significant impact on $\mathrm{CO}_{2}$ emission [18].

\section{Research Method}

This paper utilized panel data regression as Methods of data analysis. Regression analysis is a study on relationships among variables, how dependent variable reacts to one or more independent variables [23]. Panel data is the combination of cross sectional and time series data. The economic model is as follows:

$E M_{i t}=\alpha_{0}+\beta_{1} G D P P_{i t}+\beta_{2} G D P P_{i t}^{2}+\beta_{3} P O P_{i t}+$ $\beta_{4} E N_{i t}+u_{i t}$

Note

EM : Emissions

GDPP : GDP per capita

POP : Population

EN : Energy consumption

$\alpha \quad$ : Intercept or constant

$\beta \quad$ : coefficient or slope

$\mathrm{u} \quad$ : error term

i : low income countries

$\mathrm{t} \quad$ : time series

This study uses secondary data of panel data with the time frame of the year 1991-2014 and 11 low income countries, all data are retrieved from The World Bank. We use $\mathrm{CO}_{2}$ emission for emission data, GDP per capita (GDPP), Populations density (POP) for population data, and Electric power consumption (EN) for energy consumption data.

$\mathrm{CO}_{2}$ emissions are the residue of cement production process and the burning of fossil fuel. The consumption of gas fuels, gas flaring and solid and liquid materials which produce carbon dioxide also included in this category [24]. Data for $\mathrm{CO}_{2}$ are in percent of metric tons per capita

GDP per capita is the added values of economic activity in the country. GDP per capita is obtained from dividing GDP by total population. The calculation doesn't reduce quantity and degradation of natural resource. GDP is the total of production by all residents[24]. Data are in units percent of current U.S. dollars.

Population density derived from dividing total population to land area. Total Population is the number of residents regardless their citizenship. Land area is the total land territory of a country, excluding main rivers and lakes, exclusive economic zones and national claim of continental shelf [24]. Data are in units percent of people per sq. km of land area.

Electric power consumption measures production capacity of power plants [24]. Data are in units percent of $\mathrm{kWh}$ per capita.

Panel data was chosen based on the following superiority in regression [23]:

a. Data related to individuals, company, states, countries, etc. will face heterogeneity issue overtime. Panel data estimation technique will address the heteronity issue by explicitly stating specific variables-subject.

b. Panel data panel combined time series and cross sectional observation data, provide more information more variation, decrease collinearity between variables, larger degree of freedom and more efficiency.

c. Panel data is suitable for observing change dynamics due to its recurrent cross sectional observation.

d. Panel data is best in detecting and measuring an impact which is hard to see on a simple cross sectional or time series data.

e. Panel data gives better understanding in interpreting complicated behavioral model.

f. Panel data minimizes bias which often found in aggregating individuals or companies to a large aggregation.

Regression model used in this study was Fixed Effect Model (FEM), this approach is chosen because FEM can accommodate the need to see the difference in intercept and slope between periods. The assumption on Fixed Effect Approach is that the slope of independent variable is not different for each individual or between periods (times). Besides, this particular technique estimate panel data by utilizing dummy variables to capture the difference on the intercept. To avoid the panel data model from classical assumption problems such as heteroscedasticity, autocorrelation, and the possible issue of correlation between individual or spatial correlation on the regression model, this study used a DriscollKraay estimator [25].

Driscoll-Kraay estimation model is applicable for both fixed effect and common effect models. Basically Driscoll-Kraay estimator is a correction method to classical assumption violations in panel data regression model, namely the violation of heteroscedasticity 
assumption and non-auto correlation assumption both temporal correlation and cross sectional correlation.

The correction procedure in this estimator limited to standard errors, where Driscroll-Kraay using non parametric approach. Thus, Driscroll-Kraay estimator has a low difficulty level in implementation due to the non-parametric methods in the correction model procedures, which does not require numerous conditions and assumptions [26].

\section{Result and Discussions}

\subsection{Descriptive Statistics}

The result of descriptive statistics for each variable in this study is summarized in Table 1 . The number of valid observation is 246, from 11 low income countries with the time periods from the year 1991 - 2014. In general, the gap between the minimum and the maximum in each variable is quite high

Table 1. Descriptive Statistics (percent)

\begin{tabular}{|l|c|c|c|c|}
\hline \multicolumn{1}{|c|}{ Variables } & Mean & Min & Max & $\begin{array}{c}\text { Std. } \\
\text { Dev. }\end{array}$ \\
\hline Emissions & 4.219 & -55.547 & 194.441 & 20.194 \\
\hline $\begin{array}{l}\text { GDP per } \\
\text { capita }\end{array}$ & 5.446 & -62.093 & 295.022 & 23.688 \\
\hline $\begin{array}{l}\text { Populations } \\
\text { density }\end{array}$ & 2.662 & 0.996 & 5.244 & 0.740 \\
\hline $\begin{array}{l}\text { Energy } \\
\text { consumption }\end{array}$ & 3.729 & -34.586 & 120.779 & 14.665 \\
\hline
\end{tabular}

\subsection{Test Result}

The result of estimation on Fixed Effect Panel Data using Driscoll-Kraay estimator is summarized in Table 2. While cross-section fixed effects is summarized in Table 3.

Table 2. Estimation Result of Panel Data Fixed Effect Model (FEM) Driscoll-Kraay Estimator

\begin{tabular}{|l|l|}
\hline \multicolumn{1}{|c|}{ Variables } & \multicolumn{1}{c|}{$\begin{array}{c}\text { Fixed effect Model } \\
\text { Driscoll-Kraay }\end{array}$} \\
\hline Constant & $-6.502(-1.48)^{\mathrm{a}}$ \\
\hline GDP per capita & $0.205^{* * *}(3.66)$ \\
\hline GDP per capita ${ }^{2}$ & $-0.001 * * *(-6.37)$ \\
\hline Populations density & $3.344^{* *}(2.42)$ \\
\hline Energy consumption & $0.388(1.38)$ \\
\hline R-square & 0.1242 \\
\hline F test ate & $14.42^{* * *}$ \\
\hline $\begin{array}{l}\text { Note: }{ }^{\text {a }} \text { statistics are in parentheses, *** statistical } \\
\text { significance at } 0.01, * * \\
\text { statistical significance at } 0.10 .\end{array}$
\end{tabular}

Table 2 summarized per capita GDP variable has an impact to $\mathrm{CO}_{2}$ Emissions, with positive coefficient. GDP per capita ${ }^{2}$ showed that there is an impact of squared GDP per capita to $\mathrm{CO}_{2}$ Emissions in each low income countries, with negative coefficient. This result indicates that EKC has formed, which explained that an increase in per capita income initially will cause the decline in environment quality or increase $\mathrm{CO}_{2}$ emission, and to a certain point per capita income will result in improved environment quality or decreased $\mathrm{CO}_{2}$ emission. The EKC showed that there is a turning point, acquired by calculating the first derivative from the main equation. Other variables are population and energy consumptions, while the population has an impact to $\mathrm{CO}_{2}$ emissions, energy consumption has no effect to the increase or decrease of $\mathrm{CO}_{2}$ emissions

Table 3. Cross section fixed effects

\begin{tabular}{|l|c|}
\hline Countries & Cross section fixed effects \\
\hline Benin & 0.748374 \\
\hline Congo, Dem. Rep. & -1.578159 \\
\hline Ethiopia & -2.822337 \\
\hline Haiti & 7.903009 \\
\hline Mozambique & -2.402089 \\
\hline Nepal & 8.014965 \\
\hline Senegal & -1.989321 \\
\hline Togo & -0.448282 \\
\hline Tanzania & -1.767957 \\
\hline Yemen, Rep. & -5.682617 \\
\hline Zimbabwe & 0.024414 \\
\hline
\end{tabular}

\subsection{Discussions}

The correlation between per capita GDP and $\mathrm{CO}_{2}$ emissions showed as a result of this study conformed with the theory of environmental Kuznets curve [7, 8]. It means that the increase in per capita GDP will lead to environmental degradation. It is an issue of most countries particularly low-income countries, with limited capital to invest in economic development and improve their infrastructures which ultimately result in improved environmental condition. Excessive and irresponsible exploitation of natural resources with no regard to its sustainability will put a pressure on the environment, poor environmental condition will have a direct negative effect on the livelihood of the people.

On the positive note, even in low income countries an increase in per capita GPD at some point will result in a decrease in $\mathrm{CO}_{2}$ emissions. This provides good signal for future nature conservation attempts. Concerns in environmental issues will find guide light on how to harmonize economic development and sustainable environment. Government play a crucial role in achieving sustainable development, increased per capita GDP alone without a sound public policy will not solve the problem.

The research findings in line with previous studies that showed the impact of economic growth to $\mathrm{CO}_{2}$ emissions and proved the hypothesis of EKC [2, 811].and rejects the findings of previous studies that stated there is no inverted $U$ phenomenon [1, 4, 12-14].

The population relationship with environmental pollution based on results is in line with Malthus's view 
[16]. This means that increasing population status will impact increasing environmental pollution. This result is also in line with the results of research which states that increasing population will impact increasing pollution $[1,20]$. This condition has to get more attention from the government, there needs to be a city governance arrangement that supports environmental preservation. In addition, there is also a need for ongoing education where people are also concerned about environmental conditions, minimal living environment.

The relationship between energy consumption and environmental pollution shows none influence. This means that in low-income countries, energy consumption is not the main factor causing environmental pollution. However, the government needs to continue to pay attention, because however increasing energy production will be followed by increasing pollution. These results are not in line with the results of previous studies, which show energy consumption increases pollution $[1,8,18$, $21,22]$ Normatively, it can be interpreted that lowincome countries are thought to have good management related to the management of energy production so that they do not contribute to excessive pollution, or have adequate facilities and infrastructure to produce energy to reduce pollution as low as possible.

\section{Conclusion}

The findings of this study showed that in low income countries factors affecting environmental pollution are economic growth reflected in per capita GDP and population, while the energy consumption has no effect on pollution. Another findings is proven hypothesis of EKC in each country. Based on these findings it is advised that the government make an orchestrated effort in sustainable development, which put environmental soundness in center stage

\section{Acknowledgements}

The author would like to show gratitude to all parties that has supported this research, especially academics of IAIN Salatiga.

\section{References}

1. S. Park, Y. Lee, Regional model of EKC for air pollution: Evidence from the Republic of Korea, Energy Policy 39(10), 5840-5849 (2011)

2. M. Rofiuddin, T.A. Perdana, N. SBM, Economic Activity and Pollution:The case of Indonesia 19672013, J. Ekon. Pembang. Kaji. Masal. Ekon. dan Pembang. 18(2), 239, 2017.

3. C. Bozkurt, Y. Akan, International journal of energy economics and policy, Int. J. Energy Econ. Policy 4(3), 484-494 (2014)

4. K.R. Gupito, J.M. Kodoatie, Keterkaitan PDRB Perkapita dari sektor industri, transportasi, pertanian dan kehutanan terhadap kualitas lingkungan diukur dari emisi $\mathrm{CO}_{2}$ di Jawa Tengah,
Diponegoro J. Econ. 2(1), 172-178 (2013)

5. A.K. Tiwari, Energy Consumption, Co2 Emission and Economic Growth: A Revisit of the Evidence from India, Appl. Econom. Int. Dev. 11(2), 165189 (2011)

6. P. Conceição, M.V. Heitor, Techno-economic Paradigms and Latecomer Industrialization, UK (2003)

7. M. Mercan, E. Karakaya, Energy Consumption, Economic Growth and Carbon Emission: Dynamic Panel Cointegration Analysis for Selected OECD Countries, Procedia Econ. Financ. 23, 587-592 (2015)

8. M.E.H. Arouri, A.B. Youssef, H. M'henni, C. Rault, Energy consumption, economic growth and CO2 emissions in Middle East and North African countries, Energy Policy 45, 342-349 (2012)

9. P. Annicchiarico, B. Barrett, E.C. Brummer, B. Julier, A.H. Marshall, Achievements and Challenges in Improving Temperate Perennial Forage Legumes, CRC. Crit. Rev. Plant Sci. 34(13), 327-380 (2015)

10. G.-U.-R. Mir, S. Storm, Carbon Emissions and Economic Growth: Production-Based versus Consumption-Based Evidence on Decoupling, 41 (2016)

11. Y. Li, Y. Chiu, T.-Y. Lin, Y. Li, Y. Chiu, T.-Y. Lin, The Impact of Economic Growth and Air Pollution on Public Health in 31 Chinese Cities, Int. J. Environ. Res. Public Health 16(3), 393 (2019)

12. A.J. Khadaroo, R. Sultan, Economic growth and carbon emission in Mauritius: an econometric analysis in the context of the Maurice Ile Durable project, African J. Econ. Sustain. Dev. 2(3), 266 (2013)

13. H.H. Linh, S.-M. Lin, Managing global transitions: international research journal., Univerza na Primorskem, Fakulteta za Management 12(3) (2014)

14. H. Zheng, W. Huai, L. Huang, Relationship Between Pollution and Economic Growth in China: Empirical Evidence from 111 Cities, J. Urban Environ. Eng. 9(1), 22-31 (2015)

15. H.E. Chebbi, Y. Boujelbene, CO2 emissions, energy consumption and economic growth in Tunisia," 12 th Congress of the European Association of Agricultural Economists - EAAE, $1-5(2008)$

16. A.A. Aşı1, Economic growth and its impact on environment: A panel data analysis, Ecol. Indic. 24, 324-333 (2013)

17. L. Yang, S. Yuan, L. Sun, The Relationships between Economic Growth and Environmental Pollution Based on Time Series Data? An Empirical Study of Zhejiang Province, J. Cambridge Stud. 7(1), 33-42 (2012)

18. M. Zarenejad, Survey Relationship between Economic Growth and Environmental Effects of Energy Consumption (Case Study in Iran with a Non-Linear Approach), Eur. J. Exp. Biol. 2(5) (2012) 
19. Y.-J. Joo, C.S. Kim, S.-H. Yoo, Energy Consumption, Co2 Emission, and Economic Growth: Evidence from Chile, Int. J. Green Energy 12(5), 543-550 (2015)

20. G. Bella, Does pollution affect economics growth? (2003)

21. F. Halicioglu, An econometric study of $\mathrm{CO} 2$ emissions, energy consumption, income and foreign trade in Turkey, Energy Policy 37(3), 1156-1164 (2009)

22. J. Yin, L. Bian, M. Tian, X. Fan, Pursue high economic development with less pollution: implications from a Resource-Economy-Pollution dynamic system, Energy Procedia 145, 283-288 (2018)

23. D.N. Gujarati, D. Porter, Basic Econometrics, Mc
Graw-Hill International Edition (2009)

24. World Bank, Low income | Data, World Bank, (2019) Available: https://data.worldbank.org/ income-level/low-income?view=chart. Accessed: 25-May-2019

25. D. Hoechle, Robust Standard Errors for Panel Regressions with Cross-Sectional Dependence, Stata J. Promot. Commun. Stat. Stata 7(3), 281$312(2007)$

26. D. Armeanu, G. Vintilă, J.V. Andrei, Ş.C. Gherghina, M.C. Drăgoi, C. Teodor, Exploring the link between environmental pollution and economic growth in EU-28 countries: Is there an environmental Kuznets curve?, PLoS One 13(5) (2018) 